\title{
Studi Efisiensi Penyaringan Air Limbah Domestik Menggunakan Plat Beton Porous 4 Lapis Dengan Sistem Aliran Horizontal
}

\section{Aditya Wibowo $^{1 *}$, Riyanto Haribowo ${ }^{1}$, Evi N. Cahya ${ }^{1}$}

${ }^{1}$ Jurusan Teknik Pengairan, Fakultas Teknik, Universitas Brawijaya Jl. MT. Haryono No. 167, Malang, 65145, Indonesia

*Korespondensi Email: mxaditya@ student.ub.ac.id

\begin{abstract}
Limited land becomes a problem in an urban area to build IPAL. Therefore, Tlogomas Integrated MCK was created to solve this problem. By using porous concrete made from recycled aggregates measuring $0.5 \mathrm{~cm}-2 \mathrm{~cm}$ as a filtration medium, this study aims to find the efficiency of concrete in improving the quality of domestic wastewater in terms of $\mathrm{pH}$, ammonia, oil, and grease content, and total coliform bacteria. The reactor model has dimensions of $100 \times 41 \times 40 \mathrm{~cm}$ and 4 layers of the concrete bulkhead as thick as $5 \mathrm{~cm}$, with a water flow of 2 liter / minute. The reactor model was run continuously from 7 am to $5 \mathrm{pm}$ for 10 days. Samples were taken on day 1 and day 10. The efficiency of the ammonia parameter is $20.54 \%$ with the ammonia not in the wastewater quality standard. The oil and fat shows indicates that the reactor model is not as efficient as a filtration medium for this parameter. However, the parameters of oil and grease are under wastewater quality standards. The total coliform efficiency is 30.77 and is considered by the wastewater quality standard.
\end{abstract}

Keywords: Domestic Waste Water, Porous Concrete, Treatment Plant Model, Waste Water
Abstrak: Keterbatasan lahan menjadi permasalahan dalam sebuah perkotaan untuk membangun IPAL. Oleh karena itu, MCK Terpadu Tlogomas tercipta untuk mengatasi permasalahan tersebut. Dengan memanfaatkan beton porous berbahan dasar recycle agregat berukuran 0,5-2 $\mathrm{cm}$ sebagai media filtrasi, penelitian ini bertujuan untuk mencari efisiensi beton dalam memperbaiki kualitas mutu air limbah domestik ditinjau dari $\mathrm{pH}$, amoniak, minyak dan lemak serta total coliform. Model reaktor memiliki dimensi $100 \times 41 \times 40 \mathrm{~cm}^{3}$ dan sekat 4 lapis beton setebal $5 \mathrm{~cm}$ dengan debit $2 \mathrm{lt} / \mathrm{menit}$. Model reaktor ini dijalankan secara menerus dari jam 07.00-17.00 selama 10 hari. Sedangkan sampel diambil pada hari ke-1 dan ke-10. Efisiensi parameter Amonia sebesar 20,54\% dengan keadaan amonia tidak memenuhi baku mutu air limbah. 
Kemudian untuk parameter minyak \& lemak tidak efisien namun kadar minyak \& lemak memenuhi baku mutu air limbah. Dan untuk parameter total coliform terefisiensi sebesar 30,77 dan memenuhi kadar baku mutu air limbah

Kata kunci: Air Limbah Domestik, Beton Porous, IPAL.

\section{Pendahuluan}

Air limbah domestik di Kota Malang belum seluruhnya dapat tertangani, ditambah dengan sebagian besar orang membuang limbah domestik di sekitar rumah tanpa diolah terlebih dahulu [1]. Limbah domestik yang tidak dikelola dengan baik dapat menimbulkan berbagai masalah diantaranya dapat merusak kestabilan kehidupan air sungai seperti kehidupan ikan, penyebaran penyakit, bau dan dapat menurunkan nilai estetika [2]. Meningkatnya populasi penduduk yang semakin pesat diiringi dengan bertambahnya permukiman akan berpengaruh terhadap jumlah buangan limbah cair yang ditimbulkan oleh aktifitas dalam rumah tangga [3]. Hal tersebut mempengaruhi ketersediaan lahan untuk IPAL.

Pada penelitian kali ini dipilih media beton porous dari bahan recycle agregat berukuran 0,5-2 cm, yang berfungsi sebagai media filtrasi air limbah dan bersifat meneruskan air. Penggunaan RCA memberikan hasil penyaringan polutan air limbah yang lebih baik dibandingkan dengan beton porous agregat normal [4]. Dalam studi ini peneliti ingin mengetahui efisiensi filtrasi yang dilakukan oleh beton porous dalam memperbaiki kualitas mutu air limbah domestik. Utamanya parameter $\mathrm{pH}$, amoniak, minyak dan lemak, total coliform yang mengacu pada Permen LHK Nomor 68 tahun 2016 [5]. Selain itu akan dihitung pula sedimentasi yang terjadi didalam model reaktor selama proses penelitian.

\section{Bahan dan Metode}

\subsection{Bahan}

Pada penelitian ini material beton yang digunakan adalah Recycled Coarse Aggregate (RCA) berukuran 0.5-2 cm. Dengan ukuran beton porous 40x40x5 cm. Semen yang digunakan adalah semen PC merk "Semen Gresik". Sedangkan air untuk penelitian ini berasal dari air PDAM Kota Malang.

Kemudian peralatan utama yang diperlukan untuk penelitian ini adalah model reaktor berbahan akrilik dengan dimensi panjang, lebar, tinggi sebesar $100 \times 41 \times 40 \mathrm{~cm}^{3}$ dan kemiringan 5\%. Model dioperasikan secara menerus mulai jam 07.00-17.00 selama 10 hari. 


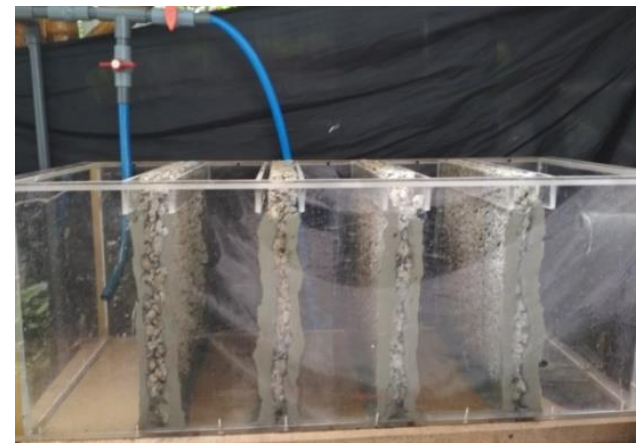

Gambar 1: Model reaktor 4 lapis

\subsection{Metode dan Tahapan Penelitian}

Penelitian ini berlokasi di MCK Terpadu Tlogomas yang terletak di Jalan Tirta Rona RT. 04 RW. 07 Kelurahan Tlogomas, Kota Malang. Dengan kolam sebanyak 14 buah yang menampung limbah domestik dari 112 KK [6]. Kondisi kolam inlet ditanami eceng gondok dan akar wangi

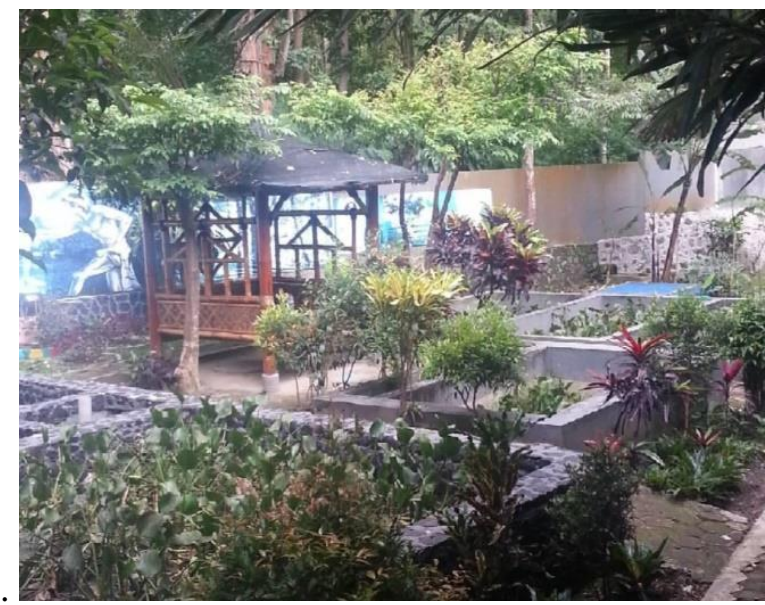

\section{Gambar 2: MCK Terpadu Tlogomas}

Tahap-tahap pelaksanaan dalam penelitian ini akan dijabarkan sebagai berikut:

1. Perencanaan Mix Design Beton Porus

Beton direncanakan berukuran 40x40x5 cm. Pada pembuatan filter beton porous ini dimulai dengan tahap pengayakan agregat, untuk memperoleh hasil ayakan berukuran 0,5$2 \mathrm{~cm}$. Kemudian dilakukan perendaman agregat minimal 24 jam hingga kondisi agregat mencapai kondisi SSD (Saturated Surface Dry) [7]. Selanjutnya dilakukan pengeringan agregat namun bukan memakai sinar matahari, melainkan dengan kain atau goni. Tahapan selanjutnya, yakni melakukan penimbangan kebutuhan semen, air dan agregat yang kemudian dimasukkan ke dalam molen untuk proses pengadukkan. Setelah adonan tercampur kemudian dicetak ke dalam bekisting yang sebelumnya sudah dilapisi plastik. Beton di curing selama 7 hari sebeum digunakan [7].

2. Desain Model dan Perencanaan Debit

Debit rencana yang akan digunakan dapat dihitung dengan cara berikut [8] :

$$
\begin{array}{rlr}
Q_{\text {rerata }} & =Q_{a b} \times \text { Jumlah orang } \times f a b & \text { Pers. } 1 \\
& =150 \mathrm{lt} / \mathrm{org} / \mathrm{hr} \times 5 \text { org } \times 0,7 & \\
& =525 \mathrm{lt} / \mathrm{hr} &
\end{array}
$$




$$
\begin{aligned}
& =0,3646 \mathrm{lt} / \mathrm{mnt} \\
& Q_{\text {hr.maks }}=f p \times Q_{\text {rerata }} \\
& =1,2 \times 0,3646 \mathrm{lt} / \mathrm{mnt} \\
& =0,4375 \mathrm{lt} / \mathrm{mnt} \\
& Q_{p} \quad=f p \times Q_{\text {hr.maks }} \\
& =2,0 \times 0,4375 \mathrm{lt} / \mathrm{mnt} \\
& =0,8750 \mathrm{lt} / \mathrm{mnt} \\
& \text { Dengan desain model berukuran } 100 \times 41 \times 40 \mathrm{~cm} \text {, ukuran filter beton porous } \\
& \text { 40x40x5 cm dan tinggin jagaan 10c m maka dihitung volume model dengan cara berikut : } \\
& V \quad=\text { Volume terendam Model }-(4 \times \text { Volume terendam Filter }) \quad \text { Pers. } 4 \\
& =123.000-(4 \times 6.150) \\
& =98.400 \mathrm{~cm}^{3} \\
& T \quad=V_{\text {total }} / Q_{\text {rencana }} \\
& =98.400 / 875 \\
& =112,46 \text { menit } \\
& \text { Dari perhitugan diatas dapat kita ketahui bahwa waktu retensi model reaktor adalah }
\end{aligned}
$$
sekitar 2 jam.

3. Pengoperasian Model Reaktor

Setelah beton porous terpasang pada model kemudian melakukan pelapisan pada samping filter brton porous yang berjarak dengan dinding dan dasar model reaktor. Hal ini dikarenakan model dibuat lebih besar $1 \mathrm{~cm}$ untuk memudahkan pemasangan filter. Kemudian dilakukan uji kebocoran pada filter. Selanjutnya pompa dihidupkan dan dilakukan pengukuran debit sesuai rencana melalui pipa dan kran yang tersedia. Model reaktor dijalankan secara kontinyu dengan pengoperasian mulai pukul 07.00 - 17.00 selama 10 hari. Jam pengoperasian dilakukan dengan mempertimbangkan jam puncak pemakaian air yang terjadi pada pukul 07.00-08.00 dan pukul 16.00-17.00.

4. Pengambilan Sampel

Pada penelitian ini parameter yang diteliti adalah $\mathrm{pH}$, amoniak, minyak dan lemak, total coliform mengacu pada Permen LHK No. 68 tahun 2016. Sampel diambil pada hari ke-1 dan hari ke-10 dimulai dari inlet hingga BAK 5. Pengambilan sampel menggunakan metode grab sampling dengan gayung bertangkai [9]. Kemudian diteruskan ke Laboraturium Kualitas Air Perum Jasa Tirta 1 Kota Malang untuk dilakukan pengujian. Pada saat di lapangan dilakukan pengukuran $\mathrm{pH}$ menggunakan $\mathrm{pH}$ meter, suhu menggunakan thermometer dan sedimentasi yang terjadi pada model reaktor.

\section{Hasil dan Pembahasan}

Setelah dilakukan sampling di MCK Terpadu Tlogomas dan pengujian di Laboratorium Kualitas Air PJT 1 Kota Malang diperoleh hasil sebagai berikut.

$3.1 \mathrm{pH}$ 


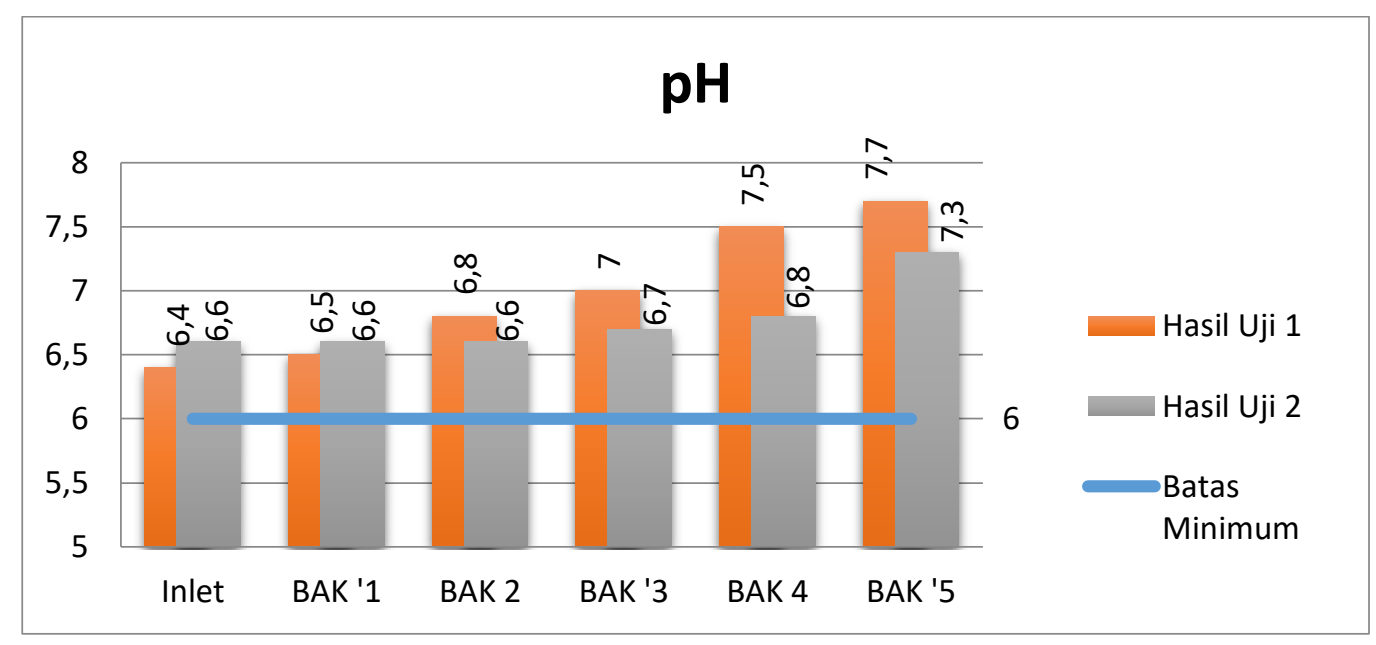

Gambar 3: Grafik Perbandingan pH pada pengujian 1 dan 2

Derajat Keasaman $(\mathrm{pH})$ Limbah yang akan diuji diambil dari inlet hingga Bak 5. Pada pengujian pertama diperoleh nilai $\mathrm{pH}$ 6,4-7,7. Kemudian pada pengujian kedua di hari ke-10 diperoleh nilai pH 6,6-7,3. Dengan tidak adanya perubahan yang terlalu signifikan pada setiap sampel penelitian dari grafik dapat kita lihat bahwa parameter $\mathrm{pH}$ masih memenuhi standar baku mutu menurut Peraturan Menteri Lingkungan Hidup Nomor 68 Tahun 2016, yakni 6,0-9,0.

\subsection{Amoniak}

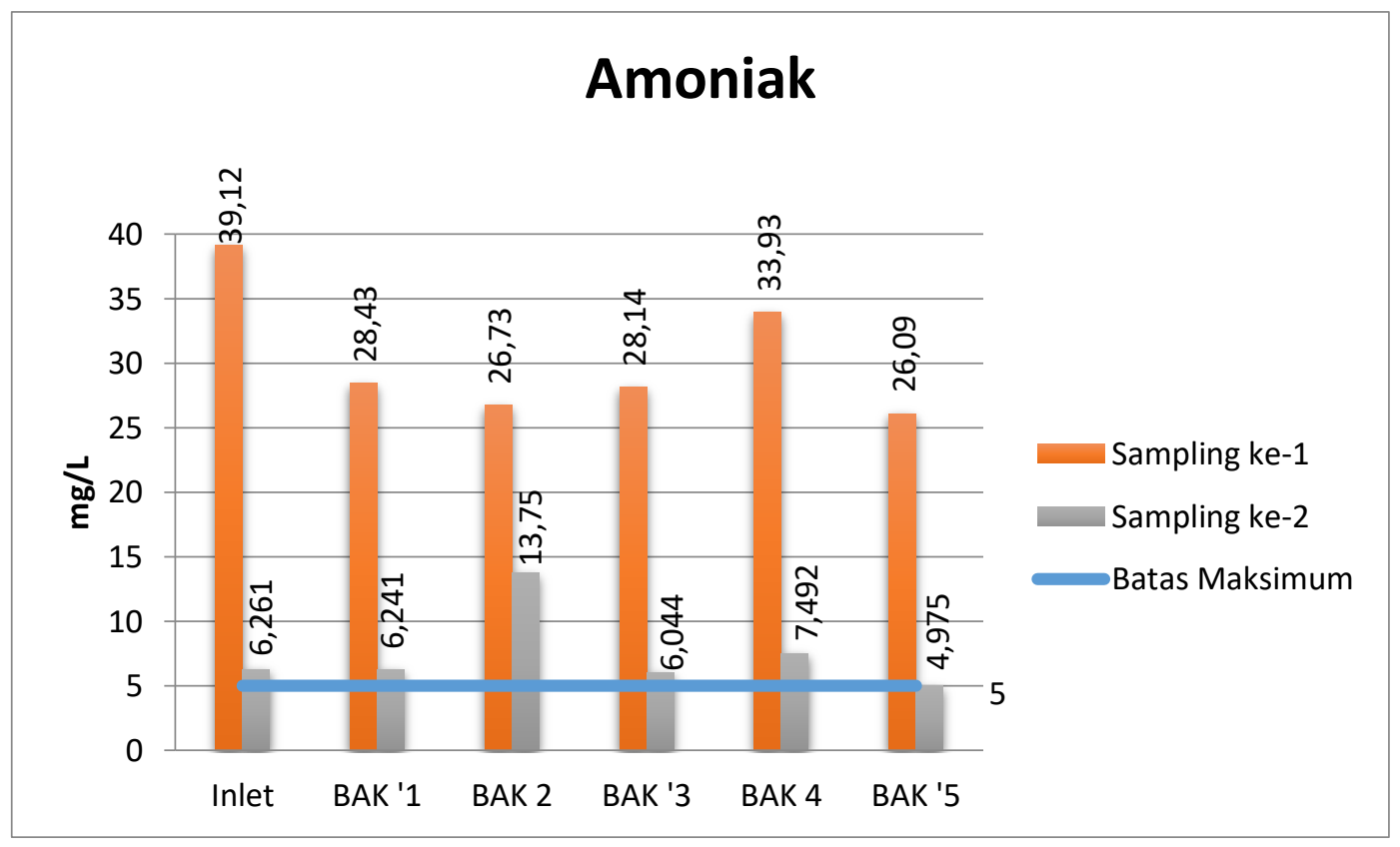

Gambar 4: Grafik Perbandingan Amoniak pada pengujian 1 dan 2

Nilai Amonia pada percobaan ini mengalami penurunan dari 28,43 pada BAK 1 menjadi 6,241 pada pengujian 1 dan 2, namun hal ini belum memenuhi standar baku mutu air limbah domestik dalam Permen LH Nomor 68 Tahun 2016, yaitu sebesar 5 mg/L. Begitu pula BAK 2 sampai BAK 4, terjadi penurunan namun belum memenuhi standar. Sedangkan 
BAK 5 pada pengujian ke-2 memenuhi standar dengan nilai 4,975. Penghilangan amoniak dapat dihilangkan dengan proses nitrifikasi. Dimana amonia (NH3) akan diubah menjadi nitrit dan kemudian menjadi nitrat. Pada proses biofilm yaitu amonia dioksidasi dan diubah menjadi nitrit di lapisan terlar media penyangga (zona aerobik) [10]. Amonia bebas yang tinggi dapat menghambat proses oksidasi amonium dan nitrit saat nitrifikasi juga hidrolisis dan asidifikasi. Amonia bebas menjadi penghambat untuk mikroorganisme berkembangbiak dalam pengolahan limbah sehingga dapat menurunkan aktivitas mikrobial [11].

3.3 Minyak dan Lemak

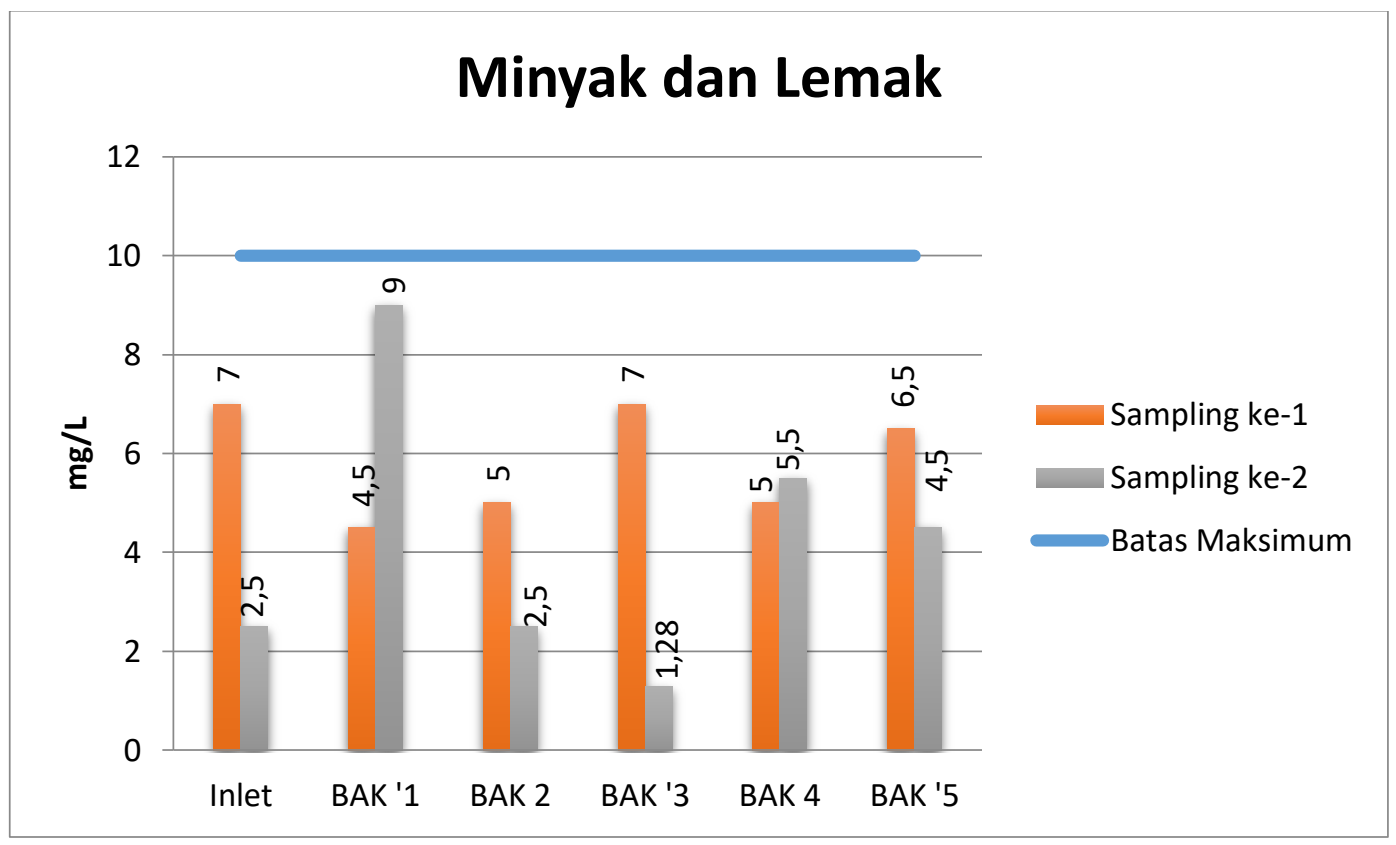

Gambar 5: Grafik Perbandingan Minyak dan Lemak pada pengujian 1 dan 2

Dari grafik dalam pengujian 1 terlihat parameter Minyak \& Lemak mengalami penurunan nilai dari inlet menuju BAK 17 -4,5. Kemudian mengalami kenaikan kembali pada BAK 2 menyentuh angka 5 dan terus naik hingga angka 7 pada BAK 3. Selanjutnya mengalami penurunan pada BAK 4 menjadi angka 5 dan naik kembali pada BAK 5 menjadi angka 6,5 pada pengujian pertama. Sedangkan pada pengujian ke-2 masih terlihat fluktuatif namun dengan angka yang lebih rendah. Dari kedua pengujian ini, untuk parameter Minyak \& Lemak dikatakan memenuhi menurut Permen LH Nomor 68 Tahun 2016. Proses pemisahan minyak dan lemak dapat dilakukan dengan dua acara yaitu cara gravitasi alami dan cara gravitasi buatan. Cara gravitasi alami dengan cara pengendap dan pemisah dimana butiran minyak naik dengan kecepatan ke atas yang dibatasi oleh berat jenisnya [10] Seperti pada saat pengukuran debit beberapa kali terjadi sedimentasi pada pipa yang tertahan selama proses pompa berhenti, dari sedimenatasi tersebut masuk ke dalam BAK 1 sehingga menyebabkan hasil fluktiatif. Adanya penumpukan minyak dan lemak berakibat menurunnya kapasitas aliran pipa dan menghambat keefektivan perlakuan pengolahan limbah sehingga diperlukan pembersihan lebih sering [12]. 


\subsection{Total Coliform}

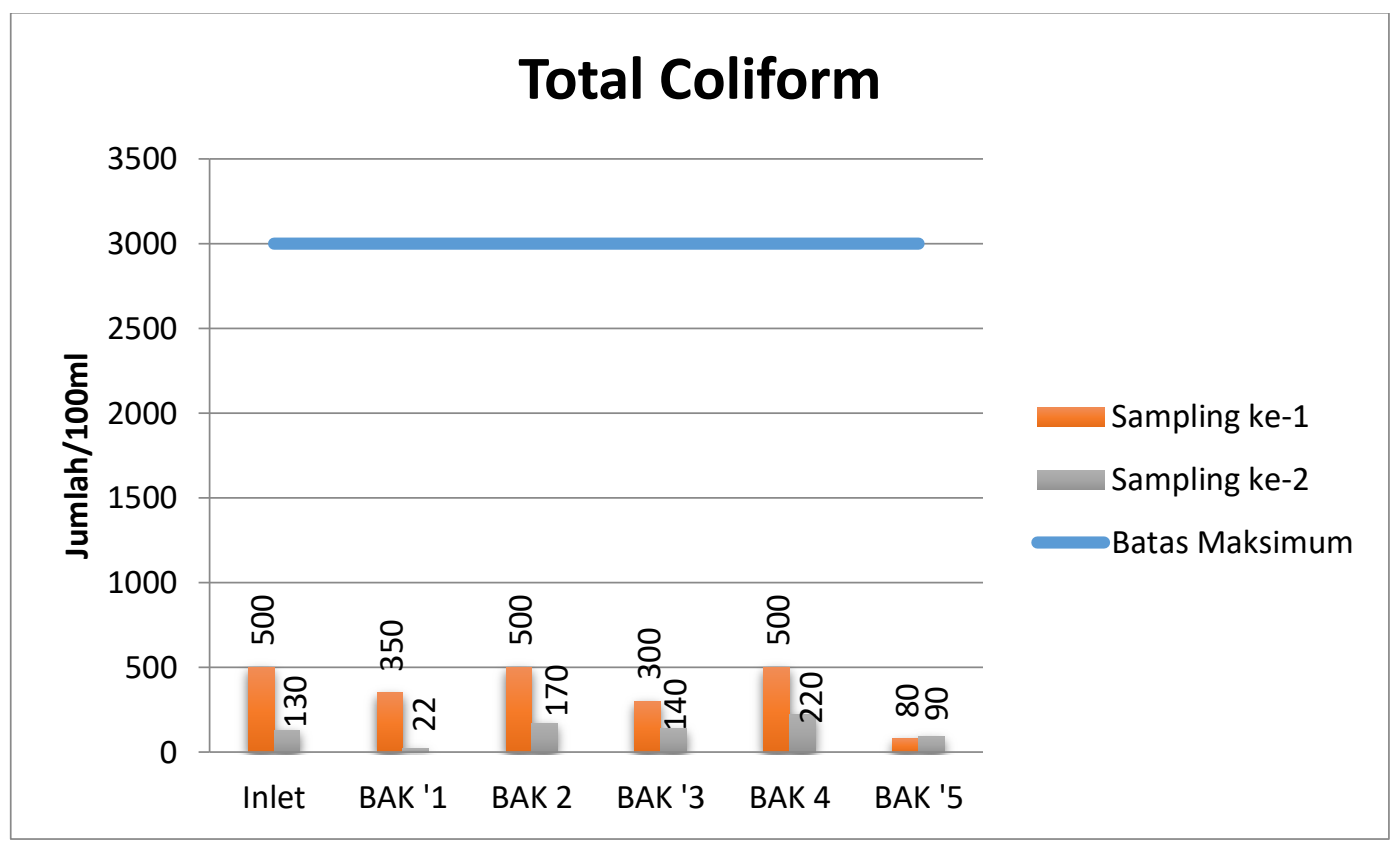

Gambar 6: Grafik Perbandingan Total Coliform pada pengujian 1 dan 2

Terlihat pada grafik bahwa parameter total coliform memenuhi batas maksimum Permen LH Nomor 68 Tahun 2016, namun yang perlu menjadi perhatian hal ini juga dapat diakibatkan dari proses sampel yang terjaga di dalam model reaktor dikarenakan aliran kontinu. Selain itu ditambah masa tunggu selama 2 jam sebelum sampel diserahkan ke pihak Lab. Kualitas Air PJT 1. Total coliform pada percobaan ini memiliki nilai 500 pada inlet pengujian pertama, sedangkan pada pengujian kedua diperoleh nilai 130. Hal ini pula dapat dipengaruhi oleh tercampurnya air limbah tersebut dengan sabun cuci yang menggandung desinfektan sehingga tidak sengaja membunuh coli yang masuk ke inlet. Seperti yang kita ketahui MCK Tlogomas adalah MCK Terpadu yang menampung langsung air limbah dari warga sekitar dan juga limbah yang masuk ke dalam inlet sudah terendapkan di dalam bak sedimentasi terlebih dahulu.

\subsection{Efisiensi}

Dari pengujian terhadap parameter, dilakukan perhitungan reduksi dan efisiensi.

\section{TABEL 1: REDUKSI PARAMETER PADA OUTLET}

\begin{tabular}{ccrrr}
\hline No. & Parameter & \multicolumn{1}{c}{ Inlet } & \multicolumn{1}{c}{ Outlet } & \multicolumn{1}{c}{ Reduksi } \\
\hline \hline 1 & Amoniak & 6,26 & 4,98 & 1,29 \\
2 & Minyak \& Lemak & 2,50 & 4,50 & $-2,00$ \\
3 & Total Coliform & 130,00 & 90,00 & 40,00 \\
\hline
\end{tabular}


TABEL 2: EFISIENSI PARAMETER PADA OUTLET

\begin{tabular}{ccrrc}
\hline No. & Parameter & \multicolumn{1}{c}{ Reduksi } & \multicolumn{1}{c}{ Efisiensi } & Keterangan \\
\hline \hline 1 & Amoniak & 1,29 & 20,54 & Efisien \\
2 & Minyak \& Lemak & $-2,00$ & $-44,44$ & Tidak Efisien \\
3 & Total Coliform & 40,00 & 30,77 & Efisien $*$ \\
\hline
\end{tabular}

Beton berpori berperan dalam proses pengolahan limbh cair secara fisik. Dalam beton ini tidak terdapat agregat halus (pasir) seperti beton konvensional yang bertujuan untuk menciptakan rongga udara yang banyak antara 15-35 \% [13]. Dari penelitian terdahulu, filter beton porous RCA 0,5-2 cm dengan 2 layer mampu mengefisiensi amoniak sebesar 9,99\%. Namun untuk total coliform, minyak dan lemak belum mampu terefisiensi karena nilai yang dihasilkan terlalu kecil [6].

Dari Tabel 1 dan 2 dapat disimpulkan bahwa percobaan ini mampu mereduksi parameter amonia sebesar 1,29. Berdasarkan nilai tersebut maka nilai efisiensi amonia pada hari ke10 untuk sampel outlet sebesar 20,54\%.

Kemudian untuk parameter minyak \& lemak belum efisien untuk mereduksi namun pada parameter ini kadar minyak \& lemak mampu memenuhi baku mutu air limbah.

Sedangkan untuk parameter total coliform mampu mereduksi sebesar 40 sehingga nilai efisiensi total coliform pada hari ke10 untuk sampel outlet sebesar $30,77 \%$.

\section{Kesimpulan}

Kapasitas model yang dibuat adalah untuk menampung 5 orang dengan debit rencana 0,875 liter/ menit dengan waktu tunggu $\pm 2 \mathrm{jam}$. Dari pengujian terlihat efisiensi parameter amonia sebesar 20,54\% dengan keadaan amonia tidak memenuhi baku mutu air limbah. Kemudian untuk parameter minyak \& lemak sebesar -44,44 tidak efisien namun kadar minyak \& lemak memenuhi baku mutu air limbah. Dan untuk parameter total coliform terefisiensi sebesar 30,77 dan memenuhi kadar baku mutu air limbah. Disaranan untuk melakukan penelitian lebih lanjut untuk mendapatkan hasil lebih maskimal.

\section{Daftar Pustaka}

[1] S. M. C. Riantika and R. Haribowo, "Efisiensi Sistem Multi Soil Layering Pada Pengolahan Air Limbah Domestik Pada Daerah Perkotaan Padat Penduduk," Jurnal Mahasiswa Jurusan Teknik Pengairan, p. 34, 2018.

[2] N. S. Karinda, T. B. Prayogi and D. Chandrasasi, "Studi Efisiensi Pengolahan Limbah Domestik Buatan Menggunakan Zig - Zag Aerator," Jurnal Mahasiswa Jurusan Teknik Pengairan, vol. 2, 2018.

[3] S. Subekti, "Pengelolaan Limbah Cair Rumah Tangga," Majalah Ilmiah Universitas Pandanaran, vol. 7, 2009. 
[4] E. N. Cahya, E. Arifi and R. Haribowo, "Recycled Porous Concrete Effectiveness for Filtration Material on Wastewater Treatment," International Journal of GEOMATE, vol. 18, no. 70, pp. 209-214, 2020.

[5] M. L. Hidup, Permen Lingkungan Hidup dan Kehutanan No.68 tahun 2016 Tentang Baku Mutu Air Limbah Domestik, Jakarta: Sekretariat Negara, 2016.

[6] A. R. M. P. Gunawan, E. N. Cahya and E. Yuliani, "Pemanfaatan Beton Poros Recycle Agregat sebagai Media Filtrasi Air Limbah Domestik MCK Terpadu Kelurahan Tlogomas Kota Malang," J. Mhs. Jur. Tek. Pengairan., vol. 1, p. 1, 2017.

[7] D. Trisnoyuwono, Beton - Non Pasir, Yogyakarta: Graha Ilmu, 2014.

[8] M. Hardjosuprapto, Penyaluran Air Buangan (PAB) Volume II, Bandung : ITB, 2000.

[9] B. S. Nasional, SNI 6989.59:2008 tentang Air dan Air Limbah-Bagian 57: Metoda Pengambilan Contoh Air Limbah, Jakarta: Republik Indonesia, 2008.

[10] N. I. Said, eknologi Pengolahan Air Limbah, Jakarta: Erlangga, 2017.

[11] Y. Liu, H. H. Ngo, W. Guo, L. Peng, D. Wang and B. Ni, "The roles of free ammonia (FA) in biological wastewater treatment processes: A review," Environment International, vol. 123, pp. 10-19, 2019.

[12] M. Dehghani, H. Sadatjo, H. Maleknia and N. Shamsedini., "A Survey on the Removal Efficiency of Fat, Oil and Grease in Shiraz Municipal Wastewater Treatment Plant," Jentashapir Journal of Health Research, 2014.

[13] A. C. 522, 522R-10: Report on Pervious Concrete, Technical Documents, 2010.

[14] Kementerian PUPR, "Permen PUPR Nomor 4 Tahun 2017 tentang Penyelenggaraa Sistem Pengelolaan Air Limbah," 2017. 